\title{
Spectrophotometic analysis of the influence of substrate on the color of dental ceramics
}

\author{
Young-Gyun Song* \\ Department of Prosthodontics, College of Dentistry, Dankook University, Cheonan, Rpublic of Korea
}

Purpose: The purpose of this study was to spectrophotometrically evaluate the influence of porcelain layer thickness and substructure. Materials and Methods: Four groups of porcelain specimens (metal and ceramic substructure) was prepared for analysis. Color parameters were measured with spectrophotometer and color difference $\left(\Delta \mathrm{E}^{*}\right)$ were calculated. T-test and one-way ANOVA test were used to find out significant difference and Tukey test was used to identify where the difference ware. Results: Increasing the thickness of porcelain decreased values $(P<0.05)$. Increasing the thickness of porcelain on ceramic substructure decreased the $a^{*}(P<0.05)$ but, the $b^{*}$ were not statistically different. Total color difference $\left(\Delta \mathrm{E}^{*}\right)$ were below 1 when the difference of porcelain thickness were $0.5 \mathrm{~mm}$. Conclusion: The thickness of porcelain are the factor effecting on color. This study will help the color are controlled by changing the thickness of porcelain clinically. (J Dent Rehabil Appl Sci 2015;31(2):96-103)

Key words: spectrophotometer; dental porcelain; color

\section{서론}

심미에 대한 환자들의 욕구가 커짐에 따라, 전치부를 비롯한 구치부 수복치료에 있어서도 수복물의 색상이 인 접치아와 조화를 이루는 것은 중요한 요소가 되었다. ${ }^{1,2}$ 치과용 수복물의 치아색상을 재현하는 도재는 17세기 프 랑스에서 언급된 이후 많은 사람들에 의하여 연구가 이 루어져 왔으며, 금속을 하부구조물로 하는 수복물은 물 론, 전부도재관에 이르기까지 다양한 수복물에 사용되고 있다. ${ }^{3,4}$ 일반적으로 치과에서 도재수복물의 정확한 색조 를 선택하기 위해 기존의 색견본과 치아를 눈으로 관찰 하여 선택하는 비색법을 사용하거나, 일부에서는 측색기 등을 통한 색조선택법을 사용하고 있다. ${ }^{2,5}$ 이렇게 선택된 색조를 재현하기 위해 불투명한 색조를 포함한 여러 색 조의 도재를 적층하여 수복물을 제작하지만, 적절한 도

*Correspondence to: Young-Gyun Song

Assistant Professor, Department of Prosthodontics, College of Dentistry, Dankook University, 119, Dandae-ro, Dongnam-gu, Cheonan, 330-714, Republic of Korea Tel: +82-41-550-1932, Fax: +82-41-550-0116, E-mail: ygsong@dankook.ac.kr Received: May 11, 2015/Last Revision: May 22, 2015/Accepted: May 22, 2015
재의 두께를 만족시키지 못하였을 경우, 색상의 재현이 어려울 경우가 있다.

색을 객관적으로 측정하기 위한 객관적 방법은 색체계 를 이용하는 것이다. 색체계(color system)는 색을 객관 적으로 표시하기 위한 방법으로 대표적으로 Munsell 색 체계, RGB 색체계 그리고, $\mathrm{CIE}$ 색체계가 있다. Munsell 색체계는 색을 색상(hue), 명도(value), 채도(chroma)로 표현하는 방법으로 일상생활에서 가장 많이 쓰이는 방 법이다. RGB 색체계는 모니터 기술과 함께 발전한 색체 계로, 빨강(red), 초록(green) 그리고, 파랑(blue)의 세가 지 색의 빛으로 원하는 색상으로 표현할 수 있다는 근거 를 가지고 있으며, 각색의 앞 글자에서 이름이 붙여졌다. $\mathrm{CIE}$ 표준 색체계는 일명 XYZ 색체계라고도 불려지며, $\mathrm{RGB}$ 색체계의 기본 3색을 기준으로 정량적인 수치 즉, 좌표로 나타낼 수 있는 색체계이다. 이 좌표를 Adams 좌

Copyright@ 2015 The Korean Academy of Stomatognathic Function and Occlusion. (c) It is identical to Creative Commons Non-Commercial License. 
표계라고 하며, 각 축은 $L^{*}, a^{*}, b^{*}$ 로 나타낸다. $L^{*}$ 은 명 도 값을 나타내며, 가장 밝은 수치를 100 으로, 가장 어두 운 수치를 0 으로 나타낸다. $a *$ 는 적색채도를 나타내며, -60 에서 +60 값을 가지며, + 값은 적색, - 값은 보색인 녹색을 나타낸다. $b^{*}$ 는 황색채도를 나타내며, $a *$ 와 동일 한 범위에서 + 값은 황색, - 값은 보색인 청색의 값을 나 타낸다. ${ }^{6,7}$

본 연구에서는 서로 다른 하부구조에서 도재의 두께 가 색조에 어떠한 영향을 미치는 지에 대하여 비교 분석 해 보고자 하였으며, 객관적인 측정을 위해 CIE L*a*b* 색체계를 이용하며 분석하였다.

\section{연구 재료 및 방법}

\section{1. 연구 재료}

본 연구에서는 치과용 주조합금인 Ni-Cr metal alloy (Verabond, AalbaDent, CA, USA)를 이용하여, 주조합 금 하부구조물을 제작하였다(Fig. 1). 세라믹계열의 하부 구조물을 불투명 Heat-pressed ceramic (HO IPS e.max Press Ivoclar Vivadent, Schaan, Liechtenstein)을 이용 한 것과 Zirconia shade block (LUXENzr, DentalMax, Seoul, Korea)을 이용한 지르코니아 하부구조물을 이 용하였다(Fig. 2). 주조합금 하부구조물에는 두 종의 도 재를 사용하였으며, Vintage MP (Shofu, Kyoto, Japan) 와 Super Porcelain EX-3 (Kuraray Noritake Dental Inc., Okayama, Japan)를 사용하였다. 완전 도재 하부구 조물 위에는 emax ceram (Ivoclar Vivadent)을 사용하

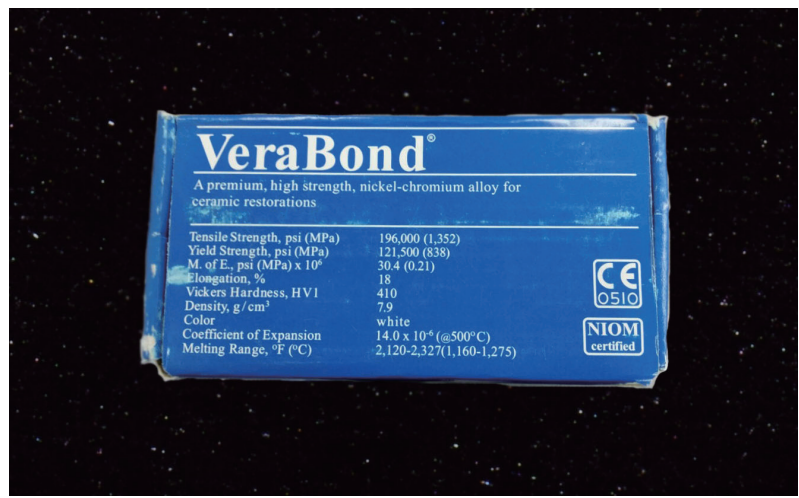

Fig. 1. Ni-Cr metal alloy (Verabond, AalbaDent, CA, USA).
였으며, 지르코니아에는 Vintage ZR (Shofu)을 사용하 여 도재를 축성하였다. 색을 객관적으로 측정하기 위해 Spectrophotometer (CM-503i, Minolta, Osaka, Japan)를 사용하였다(Fig. 3).

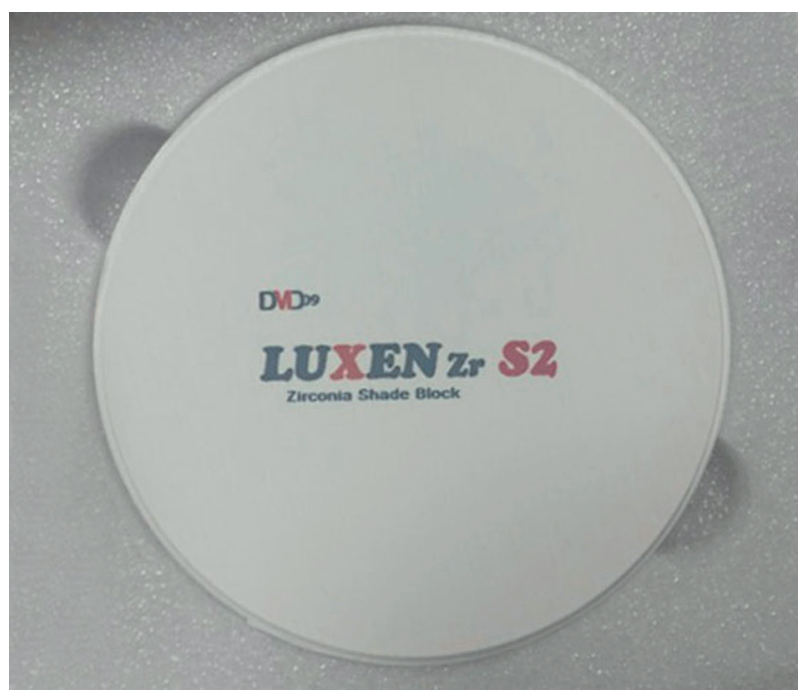

Fig. 2. Zirconia shade block (LUXENzr, DentalMax, Seoul, Korea).

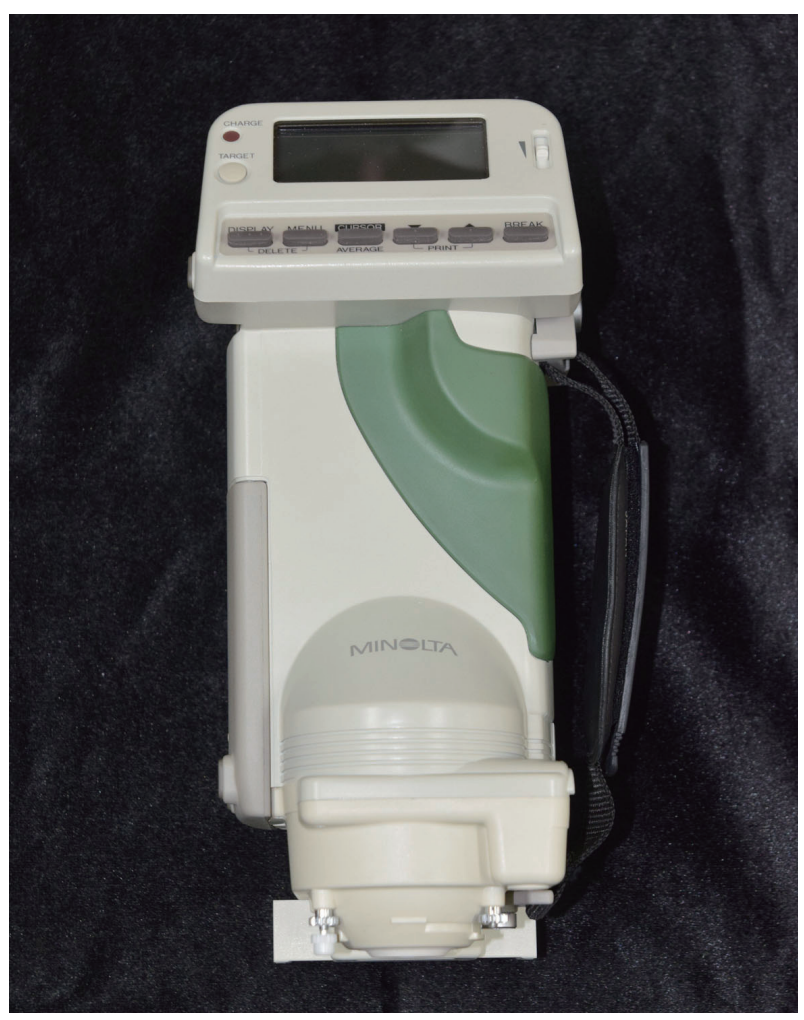

Fig. 3. Spectrophotometer (CM-503i, Minolta, Osaka, Japan) 


\section{2. 시편제작}

가. 치과용 주조합금 하부구조물

금속시편은 $1.7 \mathrm{~mm}$ 두께의 파라핀 왁스(Paraffin wax, Dae-dong, Daegu, Korea)를 이용하여 직경 $1 \mathrm{~cm}$ 의 납 형을 제작한 뒤, 제조사의 지시대로, 비귀금속 매몰재 (fugivest II, GC Co., Tokyo, Japan)를 이용하며 매몰한 뒤 주조하였다. 주조된 하부구조물은 $125 \mu \mathrm{m}$ 입자의 산 화 알루미늄(aluminium oxide)으로 2 bar의 압력으로 20 초간 공기분사연마(Air abrasion)를 시행하였다.

\section{나. 도재 하부구조물}

IPS-emax 시편은 주조합금 하부구조물과 동일한 방 법으로 납형을 제작한 뒤, IPS Pressvest Speed (Ivoclar Vivadent)를 이용하며 매몰 한 뒤, 불투명 인고트인 HO ingot를 Press furnace (IPS Empress EP 500, Ivoclar Vivadent)을 이용하며 가압주조를 시행하였다. 주조 후 매몰재를 $100 \mu \mathrm{m}$ 의 glass bead (Shofu)를 이용하여 제 거한 뒤 도재와의 결합력을 위해 invex liquid (Ivoclar Vivadent)를 이용하여, 에칭 및 세척을 시행하였다.

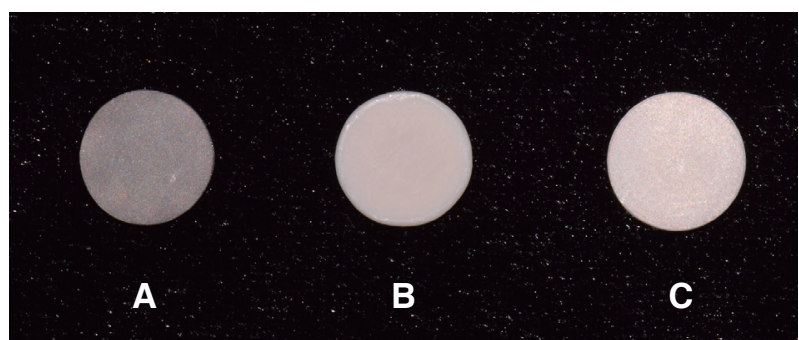

Fig. 4. Substructure of sample. (A) Ni-Cr alloy, (B) Heatpressed ceramic, (C) Zirconia block.

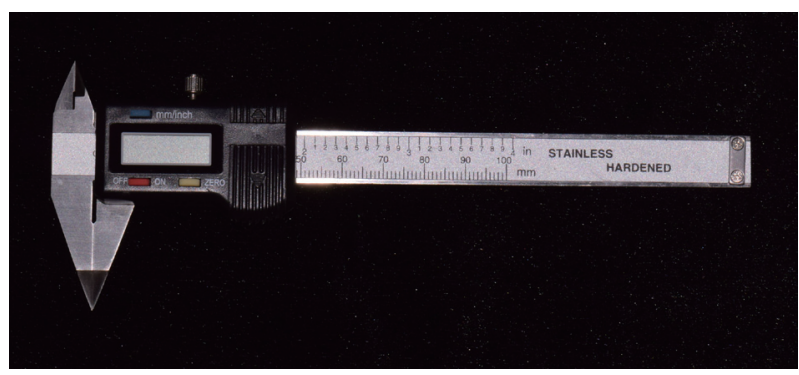

Fig. 5. Digital caliper (Orthodontic digital caliper, Jainmed, Seoul, Korea).
지르코니아 하부구조는 $\mathrm{CAD}$ 작업을 통해 직경 $1 \mathrm{~cm}$, 두께 $1.7 \mathrm{~mm}$ 의 디스크를 디자인하여 $\mathrm{CAM}$ 을 통해 제작 후 소결하였다(Fig. 4).

\section{다. 도재 축성}

금속주조 하부구조물위에 도재와 같은 회사에서 판 매되는 불투명 도재(opaque porcelain)를 통법에 따 라 3 회 축성한 뒤, 동일한 두께를 위해 전자캘리퍼 (Orthodontic digital caliper, Jainmed, Seoul, Korea)를 이용하며 두께가 균일하게 $2 \mathrm{~mm}$ 의 두께가 될 때까지 샌드페이퍼를 이용하여 연마하였다(Fig. 5). 금속주조 물 및 도재 하부구조물위에 A2 색상의 body 도재를 0.7 $\mathrm{mm}, 1.2 \mathrm{~mm}, 1.7 \mathrm{~mm}$ 그리고, $2.2 \mathrm{~mm}$ 두께를 목표로 축 성한 뒤 샌드페이퍼를 이용하여 연마하여, $0.5 \mathrm{~mm}, 1.0$ $\mathrm{mm}, 1.5 \mathrm{~mm}$ 그리고, $2.0 \mathrm{~mm}$ 로 제작하였다. 연마된 도 재는 글레이징 용액의 도포 없이 열처리만을 시행하였 다(Table1, Fig. 6).

Table 1. Materials used in the study

\begin{tabular}{ccc}
\hline Group & Substructure & Porcelain \\
\hline MP & Ni-Cr metal & Vintage MP \\
EX-3 & Ni-Cr metal & Super Porcelain EX-3 \\
& Heat-Pressed & e.max ceram \\
EMAX & ceramic & Vintage ZR \\
ZR & Zirconia & .
\end{tabular}

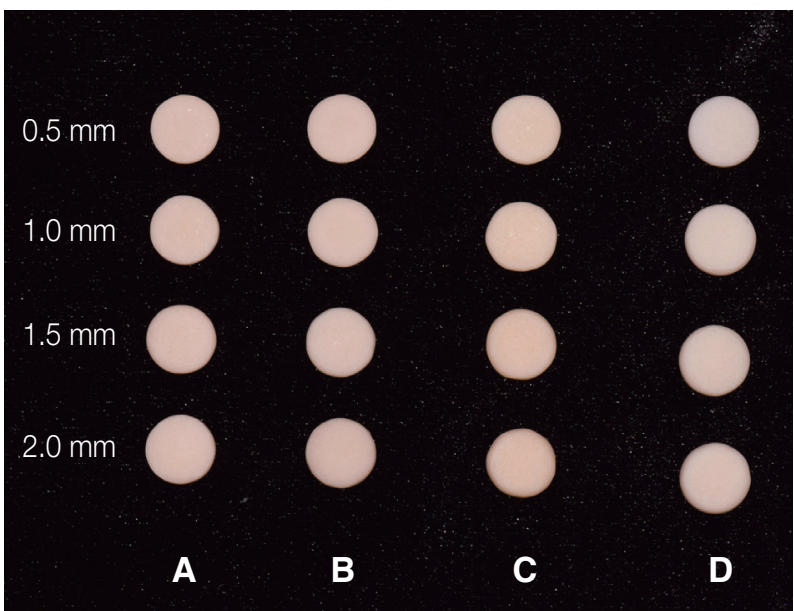

Fig. 6. Porcelain Samples of various thickness. (A) MP, (B) EX-3, (C) EMAX, (D) ZR. 


\section{3. 측색 방법}

제조사에서 추천한 방법에 따라 한 사람의 검사자가 모든 측색을 시행하였다. 광원으로는 색온도가 $6774 \mathrm{~K}$ 로 맑은 하늘 낮의 평균 직사량을 나타내는 표준광원 C 를 이용하였다. 표준백색판을 이용하여 영점을 조정한 뒤, 측정경에 시편을 밀착시킨 후, 각 시편당 3 회 측정하 였다. 각 두께당 10 개의 시편를 대상으로 하여, 총 160 개 의 시편을 대상으로 측정하였다.

\section{4. 색차값의 계산}

측색계에서 3 회 측정한 평균값이 계산되어 나오면, 산 술적 평균을 구하고 이 값을 이용하며 $\Delta \mathrm{E}^{*}$ 값을 계산하 였다. 각 측정한 측색값의 차이는 다음과 같은 공식을 이용하여 계산하였다.

$$
\begin{aligned}
\Delta \mathrm{E}^{*} & =\left\{\left(\Delta \mathrm{L}^{*}\right)^{2}+\left(\Delta \mathrm{a}^{*}\right)^{2}+\left(\Delta \mathrm{b}^{*}\right)^{2}\right\}^{1 / 2} \\
\Delta \mathrm{L}^{*} & =\mathrm{L}^{*}{ }_{1}-\mathrm{L}^{*}{ }_{2} \\
\Delta \mathrm{a}^{*} & =\mathrm{a}^{*}{ }_{1}-\mathrm{a}^{*}{ }_{2} \\
\Delta \mathrm{b}^{*} & =\mathrm{b}^{*}{ }_{1}-\mathrm{b}_{2}{ }_{2}
\end{aligned}
$$

\section{5. 통계}

통계는 IBM SPSS 19 (IBM, Chicago, IL, USA)를 이 용하여 분석하였다. 측정된 각 하부구조마다 도재 두께
의 크기에 따른 $\mathrm{L}^{*}, \mathrm{a}^{*}, \mathrm{~b}^{*}$ 값 차이의 비교는 t-test를 이 용하여 유의차를 검정하였으며, 각 블록의 색조에 따른 $\Delta \mathrm{E}^{*}$ 값의 유의차를 검정하기 위해 일원분산분석(Oneway ANOVA) 분석법을 이용하였으며, Tukey검정을 통 해 사후분석을 시행하였다. 본 논문에서 사용된 모든 통 계는 $95 \%$ 의 유의수준에서 검정되었다.

\section{결과}

측정된 측색값의 평균과 표준 편차는 다음과 같다 (Table 2). 도재 두께가 증가함에 따라 모든 실험군에서 명도가 감소하였으며, 통계적으로 유의한 차이를 보였 다 $(P<0.05)$. 도재의 두께가 증가함에 따른 $a^{*}$ 은 EMAX 군과 ZR군을 제외하고는 유의한 차이가 나타나지 않았 다. 그러나 $\mathrm{EMAX}$ 군과 $\mathrm{ZR}$ 군의 경우 $\mathrm{a}$ *값이 두께가 증 가할수록 감소하며, 이는 통계적으로 유의한 차이가 있 었다 $(P<0.05) . \mathrm{b} *$ 값의 경우 도재의 두께에 따른 유의한 차이는 없었다.

도재별로는 L*값은 차이가 없었으나, 세라믹하부구조 를 가진 $\mathrm{EMAX}$ 군과 ZR군의 경우 금속하부구조를 가진 군보다 $\mathrm{a} *$ 값이 낮았으며, $\mathrm{b} *$ 값의 경우 더 높게 나타났다 $(P<0.05$, Fig. 7).

$\Delta \mathrm{E}^{*}$ 값의 경우 $0.5 \mathrm{~mm}$ 의 두께변화에 따른 값이 1 이상 이 되는 것은 없었으나, 그 이상의 두께 차이에서는 1 이

\begin{tabular}{|c|c|c|c|c|c|c|c|c|c|c|c|c|c|c|c|}
\hline & \multicolumn{3}{|c|}{ MP } & \multicolumn{3}{|c|}{ EX-3 } & \multicolumn{3}{|c|}{ EMAX } & \multicolumn{3}{|c|}{ ZR } & \multicolumn{3}{|c|}{ Mean } \\
\hline & $\mathrm{L}^{*}$ & $a^{*}$ & $\mathrm{~b}^{*}$ & * & $a^{*}$ & * & $\mathrm{L}^{*}$ & $a^{*}$ & $b^{*}$ & * & $a^{*}$ & $b^{*}$ & L* & $a^{*}$ & $b^{*}$ \\
\hline \multirow[t]{2}{*}{$0.5 \mathrm{~mm}$} & 77.44 & 5.53 & 15.36 & 77.20 & (1) & 1. & 1 & 4.93 & 16.65 & 77.50 & 4.86 & 16.64 & 77.36 & 5.17 & 15.96 \\
\hline & $(0.50)$ & $(0.17)$ & $(0.15)$ & $(2.29)$ & $(0.26)$ & $(0.67)$ & $(0.92)$ & $(0.06)$ & $(0.72)$ & $(1.19)$ & $(0.03)$ & $(0.14)$ & $(1.56)$ & (1.33) & (2.78) \\
\hline \multirow[t]{2}{*}{ 10. $\mathrm{mm}$} & 76.75 & 5.46 & 15.07 & 76.61 & 5.18 & 15.93 & 76.84 & 4.89 & 16.21 & 76.97 & 4.73 & 16.64 & 76.79 & 5.07 & 15.91 \\
\hline & $(0.72)$ & $(0.12)$ & $(0.26)$ & $(1.35)$ & $(0.25)$ & $(0.29)$ & $(0.93)$ & $(0.05)$ & $(0.64)$ & $(0.26)$ & $(0.16)$ & $(0.51)$ & $(1.12)$ & $(0.92)$ & (1.86) \\
\hline \multirow[t]{2}{*}{$1.5 \mathrm{~mm}$} & 76.43 & 5.24 & 15.28 & 76.35 & 5.55 & 15.20 & 76.50 & 4.73 & 16.75 & 76.54 & 4.28 & 16.48 & 76.46 & 4.95 & 15.93 \\
\hline & $(0.96)$ & $(0.39)$ & $(1.45)$ & $(1.10)$ & $(0.09)$ & $(0.33)$ & $(0.62)$ & $(0.07)$ & $(0.32)$ & (1.01) & $(0.14)$ & $(0.39)$ & $(1.19)$ & $(0.60)$ & (1.46) \\
\hline \multirow[t]{2}{*}{$2.0 \mathrm{~mm}$} & 76.27 & 5.16 & 15.32 & 76.19 & 5.48 & 15.02 & 76.47 & 4.38 & 16.69 & 76.39 & 4.14 & 16.39 & 76.33 & 4.79 & 15.86 \\
\hline & $(0.84)$ & $(0.08)$ & $(0.15)$ & $(0.71)$ & $(0.23)$ & $(0.83)$ & $(0.66)$ & $(0.28)$ & $(0.23)$ & $(1.23)$ & $(0.05)$ & $(0.21)$ & (1.35) & $(0.52)$ & $(0.96)$ \\
\hline \multirow[t]{2}{*}{ Mean } & 76.72 & 5.35 & 15.26 & 76.59 & 5.39 & 15.3 & 76.78 & 4.73 & 16.58 & 76.85 & 4.50 & 16.49 & 76.74 & 4.99 & 15.92 \\
\hline & $(1.05)$ & $(0.26)$ & (1.07) & $(2.00)$ & $(0.44)$ & (1.14) & $(1.95)$ & $(0.26)$ & $(0.89)$ & (1.11) & $(0.64)$ & $(1.20)$ & $(1.46)$ & $(0.90)$ & (1.91) \\
\hline
\end{tabular}
상의 색차값을 보였다(Table 3).

Table 2. Means value of $\mathrm{L}^{*}, \mathrm{a}^{*}$ and $\mathrm{b}^{*}$ according to the thickness of porcelain

Mean (Standard deviation)

* Denote difference significant at 0.05 value. 


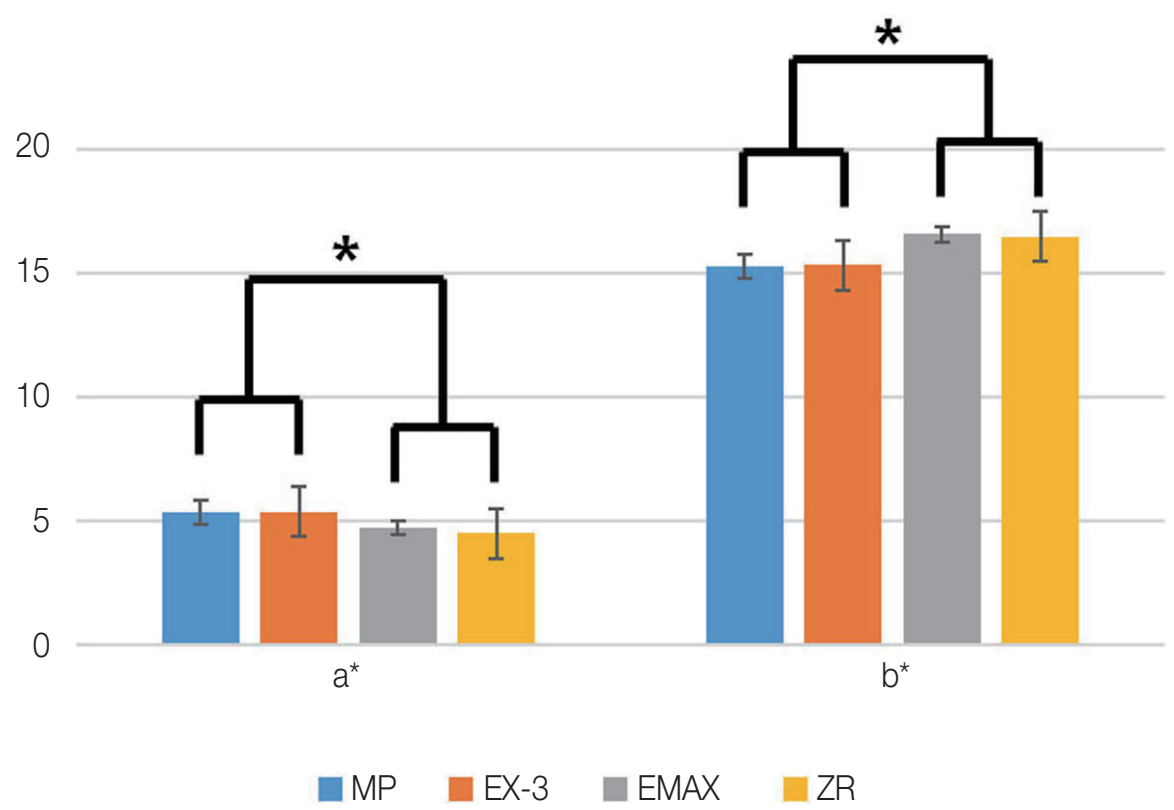

Fig. 7. Comparison of $a^{*}$ and $b^{*}$ according to samples

* denotes difference significant at 0.05 value.

Table 3. Color difference $\left(\Delta \mathrm{E}^{*}\right)$ according to the thickness of porcelain

Mean (Standard deviation)

\begin{tabular}{cccccc}
\hline & MP & EX-3 & EMAX & ZR & Mean \\
\hline $0.5 \mathrm{~mm}-1.0 \mathrm{~mm}$ & $0.75(0.04)$ & $0.58(0.10)$ & $0.65(0.05)$ & $0.96(0.12)$ & $0.58(0.08)$ \\
$1.0 \mathrm{~mm}-1.5 \mathrm{~mm}$ & $0.44(0.17)$ & $0.62(0.05)$ & $0.66(0.10)$ & $0.86(0.08)$ & $0.36(0.10)$ \\
$1.5 \mathrm{~mm}-2.0 \mathrm{~mm}$ & $0.18(0.07)$ & $0.22(0.04)$ & $0.36(0.05)$ & $0.25(0.08)$ & $0.22(0.05)$ \\
$0.5 \mathrm{~mm}-2.0 \mathrm{~mm}$ & $1.23(0.16)$ & $1.35(0.12)$ & $1.00(0.09)$ & $1.03(0.11)$ & $1.11(0.14)$ \\
\hline
\end{tabular}

\section{고찰}

도재 보철물을 이용한 수복에서 주변의 자연치와 같 은 색조를 재현하는 것은 중요한 요소 중 하나이다. ${ }^{8}$ 치 아의 색조는 하나의 치아에서도 부위에 따라 다르기 때 문에 몇 가지 색체계로 나타내기는 어렵다. ${ }^{9}$ 또한 치아 의 색은 광원의 종류나 투과 정도의 차이에 따라 색이 다르게 나타난다. ${ }^{10}$ 치아의 색조를 선택하는 방법에는 주관적인 시각적 측정법인 비색법과, 기기를 이용한 객 관적인 측정법인 측색법이 있다. ${ }^{2,5}$ 일반적으로 임상에서 는 비색법을 사용하지만, 한계가 있으며, 디지털 사진을 이용한 방법도 일종의 비색법 중 하나라고 할 수 있다. $\mathrm{CIE}$ 시스템은 가장 널리 사용되는 색체계로 $\mathrm{L}^{*}, \mathrm{a}^{*}, \mathrm{~b}^{*}$
3 가지의 좌표로 색을 정의한다. $L^{*}$ 은 Munsell 계의 명도 와 관련이 있으며, 밝기와 흑백의 무채색의 특성을 나타 낸다. $a^{*}$ 와 $b^{*}$ 는 색도좌표로 $a^{*}$ 의 값은 적색과 녹색, $b^{*}$ 의 값은 황색과 청색을 나타낸다. 두색의 색차는 $\Delta \mathrm{E}^{*}$ 로 나타내는데 $\Delta \mathrm{E}^{*}=\left\{\left(\Delta \mathrm{L}^{*}\right)^{2}+\left(\Delta \mathrm{a}^{*}\right)^{2}+\left(\Delta \mathrm{b}^{*}\right)^{2}\right\}^{1 / 2}$ 라는 식을 이용하여 구한다. 색차가 증가할 수록 두 색간의 차이가 커진다는 의미이다.

사람이 색을 인지할 때는 단순 지각반응이 아닌 생리 적, 심리적인 과정을 거치게 되기 때문에 색을 관찰할 때는 관찰자의 주관적인 심리요소가 반영되어 객관적인 평가에 어려움이 있다. ${ }^{11}$ Seghi 등 ${ }^{12}$ 의 연구에는 23 명의 치과의사와 4 명의 치과기공사의 시각적 측정을 연구한 결과 색차가 2이상의 경우 모든 실험자들이 색차를 인 
지하였으며, 2 이하의 경우 실험자마다 차이가 나타남 을 보고하였다. 일부 보고에서는 색차가 0.4 이상만 되 어도 숙련된 사람은 색차를 인지한다고 하였으나, ${ }^{11} \mathrm{O}^{\prime}$ Brien등은 $\Delta \mathrm{E}^{*}$ 이 2 이하일경우 임상적으로 허용이 가 능하며, 3.7 이상일 경우 임상적으로 확연하게 차이가 난다고 하였다. ${ }^{13,14}$ 다수의 연구와 $\mathrm{ADA}$ 기준인 색차가 2 이상일 경우 맨눈으로 색 변화를 감지할 수 있는 기준으 로 정하는 것이 더 보편적이다.

본 연구의 경우 $0.5 \mathrm{~mm}$ 도재 두께차이간의 $\Delta \mathrm{E}^{*}$ 값은 0.18 부터 0.96 의 분포로 나타났으며, 값이 1 을 넘기지 않 기 때문에 숙련되고 잘 훈련된 전문가가 아니면, 인지를 잘 못할 가능성이 있는 것으로 나타났다. 또한 도재 두께 가 $0.5 \mathrm{~mm}$ 와 $2.0 \mathrm{~mm}$ 사이에는 1 이상의 $\Delta \mathrm{E}^{*}$ 값을 보였 으며, 특히 하부구조물이 금속의 경우에는 수치가 더 큰 것으로 나타났다. 이것은 하부금속구조물에 적용된 불 투명도재 때문일 것으로 사료되며, 따라서 하부구조물 이 금속구조물일 경우에는 도재 두께차이에 따른 색상 의 차이가 완전도재수복물보다 더 클 것으로 사료된다.

기존의 연구에 따르면, $\mathrm{A} 2$ 색상의 경우 $\mathrm{L}^{*}$ 의 값은 $76.04, a *$ 값은 -0.08 그리고, $b^{*}$ 값은 16.73 인 것으로 보고 되었다. ${ }^{15}$ 이번 연구와는 값의 차이를 보였는데, 이것은 본 실험에서는 dentin powder만을 사용하여 body부분 을 축성하여 실험을 한 것이기 때문에 enamel층과 투명 층을 적층축성하여 제작한 완성된 도재 보철물과는 차 이가 있을 것으로 사료된다.

$\mathrm{CIE}$ 색체계에서 객관화된 표준광원에는 $\mathrm{A}$ 는 색온도 가 $2854 \mathrm{~K}$ 인 백열등을 나타내며, B는 색온도 $2879 \mathrm{~K}$ 로 오후의 자연광을 나타낸다. 표준광원 $\mathrm{C}$ 는 $6770 \mathrm{~K}$ 의 색 온도를 가지며, 표준광 A에 C종의 Davis-Gibson필터를 첨부하여 만든 빛으로 푸른 하늘을 포함하는 평균주광 을 나타내며, $\mathrm{D}$ 는 평균적인 자연광인 색온도 $6500 \mathrm{~K}$ 을 나타낸다. 본 연구에서 사용된 spectrophotometer는 여 러 표준광원을 선택할 수 있기 때문에 표준광원 $\mathrm{C}$ 를 사 용하였으며, 구경 $3 \mathrm{~mm}$ 의 측정경에 관찰할 시편을 두 고 측정하며, 물체로부터 반사된 빛의 스펙트럼을 분석 하여 색상을 색체계로 나타내는 방식이다. 측색과정 중 측정경과 시편 사이의 틈을 통해 들어오는 외부의 빛을 최소화하기 위해 어두운 환경에서 측정을 시행하였다.

이전의 연구에서는 도재의 색상을 잘 나타내기 위해 두께에 대한 여러 연구가 있었다. Dougla 등은 shade guide와 도재의 색조가 일치하기 위해서는 1-2 $\mathrm{mm}$ 의 도재의 두께가 필요하다고 하였다. ${ }^{16}$ 다른 연구에서는 백
류석 강화도재를 사용하였을 경우 core를 가리기 위해서 는 $1.6 \mathrm{~mm}$ 이상의 도재두께가 있어야 한다고 보고하였 다. ${ }^{17}$ 본 연구에서는 시편의 다양성과 도재의 두께를 단 순비교하기 위하여, 불투명도재를 제외한 부분의 두께 를 기준으로 비교 분석하였으며, 적절한 두께를 찾기보 다는 두께가 증가할수록 변하는 수치를 중심으로 살펴 보았다. 따라서 본 연구를 기준으로 적절한 도재의 두께 를 설정하는 것은 어려울 것으로 사료되지만, 도재의 두 께를 증가시키거나 감소시킬 때 나타날 수 있는 현상을 추측하는 것에는 많은 도움이 될 것이라고 사료된다.

모든 하부구조는 조건을 최대한 일치시키려고 노력하 였으며, 금속하부구조에는 불투명도재를 처리하였다. Barghi 등은 금속의 색을 완전히 차단하기 위해 $0.3 \mathrm{~mm}$ 의 불투명도재가 필요하다고 하였는데 이것을 기준으로 하여 금속을 하부구조물의 불투명도재의 두께를 설정하 였다. ${ }^{18}$ 그 외의 세라믹 하부구조물은 불투명한 도재를 사용하여 하부구조물 자체의 색상에 대한 영향을 최소 화하려 하였다. 이번 연구결과에서 A2 색상의 기준 명 도보다 모두 밝은 $\mathrm{L} *$ 값을 보이는 이유도 불투명한 하부 구조물때문인 것으로 사료되며, 도재의 두께가 증가할 수록 $\mathrm{L}^{*}$ 값이 낮아지는 이유도 불투명 도재의 영향이 줄 어들기 때문인 것으로 사료된다. ${ }^{18}$

이번 연구에서는 일반적으로 도재의 두께를 결정하는 dentin 도재에 한정해서 도재 두께와 색상에 대한 비교 분석을 시행하였다. 동일한 하부구조라도 두께에 따라 측색값이 서로 다르게 나타나기 때문에, 치아의 삭제량 에 따라 하부구조의 두께나 필요시 추가삭제 등의 고려 가 필요할 것으로 생각되며 이때 원하는 색상을 위한 도 재의 두께의 변화방향을 가늠하기 위해 도움이 될 것이 라고 생각된다.

앞으로 임상에서 더욱 도움이 되기 위해서는 enamel 층이나 투명층의 두께에 대한 관계 및 서로 다른 층과의 관계분석이 추가로 필요할 것이라고 생각된다. 또한 완 전한 도재층들을 평가하고자 할 때에는 CIE 색체계뿐 만 아니라 비색법에 많이 사용되는 shade guide 식 표현 을 기준으로 평가하는 것이 더 좋은 평가가 될 것이라 사료된다.

\section{결론}

도재보철물의 색상을 결정하는 요소에는 많은 것들이 있다. 그 중 도재의 두께는 색상에 영향을 줄 수 있는 중 요한 요소로, 도재 두께의 차이에 따른 도재의 색상연구 
결과 다음과 같은 결론을 얻었다.

1. 도재 두께가 증가함에 따라 모든 실험군에서 명도 가 감소한다.

2. 세라믹 하부구조물의 보철물은 도재의 두께가 증 가 할수록 $\mathrm{a} *$ 값이 감소한다.

3. 도재의 두께는 b*값에 유의한 영향을 주지 않는다.

4. 도재 두께 차이가 $0.5 \mathrm{~mm}$ 이하일 경우 $\Delta \mathrm{E}^{*}$ 값이 1 이하로 육안으로 구분하기 어렵다.

\section{Acknowledgements}

이 연구는 2013학년도 단국대학교 대학연구비 지원으 로 연구되었음.

\section{Orcid}

Young-Gyun Song http://orcid.org/0000-0003-3789-9585

\section{References}

1. Rhu SY, Lee JH, Cho IH. A study on the color stability of porcelain for porcelain fused to metal crown. J Korean Acad Prosthodont 2000;38:73-84.

2. Paravina RD, Powers JM, Fay RM. Color comparison of two shade guides. Int J Prosthodont 2002;15:73-8.

3. Campbell SD. A comparative strength study of metal ceramic and all ceramic esthetic materials: modulus of rupture. J Prosthet Dent 1989;62:4769.

4. Crispin BJ, Jo YH, Hobo S. Esthetic ceramic restorative materials and techniques. In: Crispin BJ, editor. Contemporary esthetic dentistry: practice fundamentals. Chicago; Quintessence Publishing Co.; 1994. p. 155-188.

5. Paul S, Peter A, Pietrobon N, Hämmerle CH. Visual and spectrophotometric shade analysis of human teeth. J Dent Res 2002;81:578-82.

6. Sproull RC. Color matching in dentistry. II. Practical application for the organization of color. J Prosthet Dent 1973;29:556-66.

7. Asano S, Yamamoto M. Optimal tooth shade verification technique. QDT 2002;5:30-57.

8. Paravina RD. Evaluation of a newly developed visual shade-matching apparatus. Int J Prosthodont 2002;15:528-34.

9. Kim CS, Lim JS, Jung CM, Jeon YC. Colorimetric analysis of color differences between dentin porcelains. J Korean Acad Prosthodont 1999;37:425-32.

10. Seleski CG. Color, light, and shade matching. J Prosthet Dent 1972;27:263-8.

11. Goldstein GR, Schmitt GW. Repeatability of a specially designed intraoral colorimeter. J Prosthet Dent 1993;69:616-9.

12. Seghi RR. Effects of instrument-measuring geometry on colorimetric assessments of dental porcelains. J Dent Res 1990;69:1180-3.

13. O’Brien WJ, Groh CL, Boenke KM. A new, smallcolor-difference equation for dental shade. J Dent Res 1990;69:1762-4.

14. Johnston WM, Kao EC. Assessment of appearance match by visual observation and clinical colorimetry. J Dent Res 1989;68:819-22.

15. O’Brien WJ, Groh CL, Boenke KM. One-dimensional color order system for dental shade guides. Dent Mater 1989;5:371-4.

16. Douglas RD, Przybylska M. Predicting porcelain thickness required for dental shade matches. J Prosthet Dent 1999;82:143-9.

17. Nakamura T, Saito O, Fuyikawa J, Ishigaki S. Influence of abutment substrate and ceramic thickness on the colour of heat-pressed ceramic crowns. J Oral Rehabil 2002;29:805-9.

18. Barghi N, Lorenzana RE. Optimum thickness of opaque and body porcelain. J Prosthet Dent 1982; 48:429-31. 


\section{하부구조물 및 두께에 따른 치과 수복용 세라믹의 색조에 대한 분광측색분석}

\section{송영균}

단국대학교 치과대학 치과보철학교실

목적: 본 연구는 하부구조물과 축성된 도재의 두께 차이에 따른 색상의 차이를 비교연구하여 보고자 함이다.

연구 재료 및 방법: 금속하부구조물과 완전도재 하부구조물위에 $0.5 \mathrm{~mm}$ 간격으로 도재의 두께를 다르게 축성을 한 후 에 spectrophotometer를 이용하여, 색상을 측정하였다. 이후 측색값과 $\Delta \mathrm{E}$ *값을 통계학적으로 비교 분석하였다.

결과: 도재의 두께가 증가함에 따라 명도가 감소하였다 $(P<0.05)$. 세라믹 하부구조물의 경우 축성된 도재의 두께가 증 가할수록 $\mathrm{a}^{*}$ 값이 감소였으나 $(P<0.05)$, 두께는 $\mathrm{b}^{*}$ 값에 유의한 영향을 주지 않았다. 도재 두께 차이가 $0.5 \mathrm{~mm}$ 이하일 경우 $\Delta \mathrm{E}^{*}$ 값이 1 이하였다.

결론: 하부구조물의 종류에 따라 차이가 있으나, 도재의 두께가 색상에 영향을 주는 요소이며, 두께에 따른 색조 변화 양상의 인지를 통하여, 임상에서 도재 두께변화를 이용한 색상조절에 도움이 될 것이라 사료된다.

(구강회복응용과학지 2015;31 (2):96-103)

주요어: 측색기; 치과용 도재; 색상 